\title{
Microbial dynamics associated with decomposing Typha angustifolia litter in two contrasting Lake Erie coastal wetlands
}

\author{
Rong Su${ }^{1}$, Rachel N. Lohner ${ }^{2}$, Kevin A. Kuehn ${ }^{1,3, *}$, Robert Sinsabaugh $^{2,4}{ }^{2}$ Robert K. Neely ${ }^{1}$ \\ ${ }^{1}$ Department of Biology, Eastern Michigan University, Ypsilanti, Michigan 48197, USA \\ ${ }^{2}$ Department of Earth, Ecological and Environmental Science, University of Toledo, Toledo, Ohio 43606, USA \\ ${ }^{3}$ Present address: Department of Biological Sciences, The University of Southern Mississippi, Hattiesburg, \\ Mississippi 39402, USA \\ ${ }^{4}$ Present address: Department of Biology, University of New Mexico, Albuquerque, New Mexico 87131, USA
}

\begin{abstract}
We compared the decomposition of sediment-associated litter of Typha angustifolia in 2 Lake Erie coastal wetlands, examining the effects of sedimentation on microbial biomass, production and litter decay dynamics. Experimental manipulations of sediment had no statistically significant effect ( $p>0.05$ ) on microbial biomass or metabolism. However, unforeseen differences between wetland sites (i.e. permanently inundated vs. exposed) had a major influence on microbial colonization and growth, litter mass loss, and nutrient dynamics. Litter-associated bacterial biomass and production were greater at the inundated site vs. the exposed wetland site (e.g. 487 vs. $158 \mu \mathrm{g} \mathrm{C} \mathrm{g}^{-1}$ detrital $\mathrm{C}$ after $146 \mathrm{~d}$, respectively). In contrast, fungal biomass and production were greater at the exposed site (e.g. 125 vs. $56 \mathrm{mg} \mathrm{C} \mathrm{g}^{-1}$ detrital C after $146 \mathrm{~d}$, respectively). Microbial degradative enzymes involved in the acquisition of phosphorus, nitrogen and carbon followed similar patterns as observed for fungal biomass and production, with higher activities associated with decaying litter at the exposed site. Microbial respiration rates were initially similar at both sites, but increased at the inundated site towards the end of the study period. Despite greater litter-associated microbial biomass, production and enzyme activities at the exposed wetland site, rates of litter mass loss were similar, suggesting that the greater metabolic potential of microbiota at the exposed site may have been offset by environmental conditions (e.g. fluctuations in water availability). Although mass loss rates were similar, significant differences in nutrient dynamics were observed, with higher $\mathrm{N}$ and $\mathrm{P}$ associated with higher litter-associated microbial biomass. These results illustrate how microbial decay dynamics can potentially interact with environmental variables (e.g. water availability) to modulate the carbon and nutrient dynamics of a litter resource that dominates many wetlands.
\end{abstract}

KEY WORDS: Wetlands - Sedimentation $\cdot$ Litter $\cdot$ Decomposition $\cdot$ Fungi $\cdot$ Bacteria $\cdot$ Nitrogen · Phosphorus

Resale or republication not permitted without written consent of the publisher

\section{INTRODUCTION}

The Great Lakes region contains approximately $1209 \mathrm{~km}^{2}$ of wetland surface area distributed across 1370 distinct coastal wetlands along the United States shorelines alone (Herdendorf et al. 1981). Emergent vascular plants, such as the genera Typha, Carex and Scirpus, frequently dominate annual net primary production (NPP, $>2 \mathrm{~kg} \mathrm{~m}^{-2} \mathrm{yr}^{-1}$ ) within these coastal wetlands and serve as important reservoirs of nutrients (Mitsch \& Gosselink 2000). As a consequence, these emergent plant communities can influence nearly all the structural and functional aspects of these wetlands, as well as the nutrient and metabolic characteristics of adjacent lake ecosystems (Wetzel 1990, 1992). 
In many freshwater wetlands, most of the annual plant production is not consumed during the growing season (e.g. Wetzel \& Howe 1999), but eventually enters the detritus pool where it is broken down and mineralized by microorganisms. These processes mediate the retention and release of nutrients sequestered in plant tissues and control the flow of carbon and nutrients to higher trophic levels (Mann 1988, Hopkinson 1992). One factor affecting plant litter decomposition is sedimentation. Sediment retention is often cited as a beneficial function of wetlands (Mitsch \& Gosselink 2000); however, elevated sediment accumulation may represent a disturbance with potentially negative consequences for important detrital processes. Vargo et al. (1998) reported significant decreases in both the mass loss rate and $\mathrm{N}$ concentration of sediment-associated Typha latifolia litter exposed to experimental increases in sediment deposition. Additional research by Martin \& Neely (2000) also demonstrated significant declines in total benthic macroinvertebrate density and richness in response to sediment additions to a T. angustifolia marsh, further pointing to a potential sediment-induced impact on detrital-based food-webs.

Despite an abundance of quantitative data on plant litter decay and nutrient cycling in wetlands (e.g. Brinson et al. 1981, Polunin 1984, Webster \& Benfield 1986, Bayley \& Mewhort 2004), the effects of sedimentation on wetland litter decay processes have not been related to the composition and dynamics of the microbial decomposer communities that control nutrient retention/release and the fate of carbon. We evaluated these connections by comparing microbial community metabolism (i.e. biomass, production and respiration of bacteria and fungi) and extracellular enzyme activities associated with the decomposition of Typha angustifolia leaf litter in 2 Lake Erie coastal wetlands under varied sedimentation regimes. Microbial dynamics were compared to litter mass loss rate and immobilization of $\mathrm{N}$ and $\mathrm{P}$. These data provide an integrated 'bottom-up' view of microbial decomposition for a resource that dominates the carbon and energy dynamics of many freshwater wetlands.

\section{MATERIALS AND METHODS}

Study site. This study was conducted from June 2001 through September 2002 in 2 Lake Erie coastal wetlands: Winous Point (WP) and Lake Erie Metro Park (LEMP). The WP wetland is located in the Winous Point Conservation Area on the SW shore of Lake Erie near Port Clinton, Ohio $\left(41^{\circ} 28^{\prime} \mathrm{N}, 82^{\circ} 59^{\prime} \mathrm{W}\right)$. The study site was situated in a western portion of the marsh in a zone dominated by the emergent macro- phyte Typha angustifolia and Nulumbo lutea. The site is isolated from nearby Sandusky Bay by earthen dike impoundments. LEMP is located on the NW shore of Lake Erie at the mouth of the Detroit River, near Brownstone, Michigan $\left(42^{\circ} 04^{\prime} \mathrm{N}, 83^{\circ} 14^{\prime} \mathrm{W}\right)$. This site is a more hydrologically open system, containing a variety of habitats that freely interact with Lake Erie. The site is dominated by the emergent macrophytes Phragmites australis and T. angustifolia.

Experimental design. A randomized block design was used to investigate the effects of sediment size and loading rates on microbial decay of Typha angustifolia litter within these 2 wetland sites; 15 enclosures were randomly established at each site. Enclosures were $1.5 \mathrm{~m}$ long $\times 1.5 \mathrm{~m}$ wide $\times 1.0 \mathrm{~m}$ high and constructed using $1 \mathrm{~mm}$ fiberglass mesh and PVC tubing supports. Three enclosures were randomly assigned to 1 of 5 sediment treatments: control (no added sediment), single fine sediment (clay) application, multiple fine applications, single coarse sediment application, and multiple coarse applications. Goldart clay (Rovin Ceramics) with an average particle size of $5.8 \pm 1.6 \mu \mathrm{m}$ was used for fine sediment applications. Coarse sediment applications used natural sediment collected from the corresponding wetland sites. Collected sediment was air dried and passed through a $2.5 \mathrm{~mm}^{2}$ standard sifting screen before application in the enclosures. Previous studies using this technique for wetland sediments in SE Michigan reported that sediment particle sizes averaged $201 \pm 17 \mu \mathrm{m}$ (Vargo et al. 1998). Each sediment application resulted in a deposition of $1633 \mathrm{~g}$ of sediment, which was equivalent to $725 \mathrm{~g} \mathrm{~m}^{-2}$ or a sediment layer of $0.8 \mathrm{~mm}$. This amount reflects natural sediment inputs of 1 to $2 \mathrm{~cm} \mathrm{yr}^{-1}$, which generally arrive episodically throughout the year.

Field procedures. Over-wintered standing-dead leaf litter of Typha angustifolia (upper $1 / 3$ of leaf blade) was collected at LEMP and WP in March and May 2001, respectively. Collected litter was returned to the laboratory, air-dried, cut into ca. five $10 \mathrm{~cm}$ pieces; ca. $3 \mathrm{~g}$ of litter was enclosed in $20 \times 15 \mathrm{~cm}$ plastic coarse ( $5 \mathrm{~mm}$ ) mesh litter bags. Additional litter samples were dried $\left(60^{\circ} \mathrm{C}\right)$, weighed, and ashed $\left(\geq 4 \mathrm{~h}\right.$ at $\left.500^{\circ} \mathrm{C}\right)$ for determination of air-dried mass to ash-free dry mass (AFDM) ratios. Twenty litter bags containing corresponding $T$. angustifolia litter from each wetland site were either submerged (WP) or placed in a single layer on the sediment surface (LEMP) within each enclosure in May 2001. Single sediment applications (fine or coarse) to the treatment enclosures were conducted on the first sampling date only. Multiple sediment applications were performed monthly. Sediment additions were applied to the treatment enclosures in the form of slurry, which was sprinkled from a common perforated watering can. 
Three litter bags from each enclosure were retrieved periodically on 5 occasions from June 2001 to September 2002, placed on ice in a cooler, and returned to the laboratory. One litter bag from each enclosure was used for the determination of litter mass loss rates and nutrient concentrations. The remaining litter bags were used for determination of microbial biomass and production (bacteria and fungi), rates of microbial respiration, microbial enzyme activities, and dissolved organic carbon (DOC) release.

Mass loss and nutrient contents. Intact plant material was removed from litter bags, washed gently to free adhering macroinvertebrates, and dried at $60^{\circ} \mathrm{C}$ to a constant weight. Dried plant material was ground to a $425 \mu \mathrm{m}$ particle size (40 mesh) using a Wiley mill, and subsamples combusted ( $\geq 4 \mathrm{~h}$ at $500^{\circ} \mathrm{C}$ ) to determine the AFDM remaining. Litter decay rates $(-k)$ were calculated using a nonlinear $\left(M_{t}=M_{0} \times \mathrm{e}^{-k t}\right)$ regression model and a linear regression model after log transformation $\left(\ln \left(M_{t} / M_{0}\right)=-k t+\mathrm{b}\right)$, where $M_{t}$ is the AFDM at Time $t(\mathrm{~d})$ and $M_{0}$ is the initial \% AFDM in the litter bags. Nitrogen and phosphorus concentrations (\%) were determined spectrophotometrically using a BranLubbe Autoanalyzer II System (Bran-Lubbe Methods: 696-82W and 455-762/A) after high temperature $\left(390^{\circ} \mathrm{C}\right.$ ) digestion of ground litter subsamples (ca. 300 mg dry wt) in $\mathrm{CuSO}_{4}$ /sulphuric acid (see Kuehn \& Suberkropp 1998a) using a Bran-Lubbe block digester.

Bacterial productivity and biomass. Bacterial productivity associated with Typha angustifolia litter was estimated from rates of ${ }^{3} \mathrm{H}$-thymidine (TdR) incorporation into bacterial deoxyribonucleic acid (DNA) (see Sinsabaugh \& Findlay 1995). Subsamples (ca. $50 \mathrm{mg}$ dry wt) of leaf litter from litter bags were placed in sterile $15 \mathrm{ml}$ centrifuge tubes containing $5 \mathrm{ml}$ of membrane-filtered $(0.22 \mu \mathrm{m})$ wetland water and $1.48 \mathrm{MBq}$ ${ }^{3} \mathrm{H}$-thymidine (specific activity $=3 \mathrm{TBq} \mathrm{mmol}^{-1}$, Amersham Biosciences), vortexed, and incubated for $1 \mathrm{~h}$ at $23^{\circ} \mathrm{C}_{\text {; }} 4$ replicates and 2 formalin-killed controls were run for each litter bag sample. After incubation, $5 \mathrm{ml}$ of $10 \%$ buffered formalin were added to the sample tubes and vortexed. Extraction and quantification of radiolabeled DNA from incubated samples followed procedures described in Sinsabaugh \& Findlay (1995). Results were calculated as $\mu \mathrm{g}$ of bacterial $\mathrm{C}$ produced $\mathrm{g}^{-1}$ detrital $\mathrm{C} \mathrm{d}^{-1}$ using conversion factors of $2 \times 10^{9}$ bacterial cells produced $\mathrm{nmol}^{-1} \mathrm{TdR}$ incorporated and the mean bacterial $\mathrm{C}$ content based on bacterial biovolume estimates from epifluorescence direct count microscopy (see below).

Bacterial biomass associated with litter was determined by epifluorescence microscopy after staining with SYBR Green I (Molecular Probes) (see Noble \& Fuhrman 1998). Subsamples of leaf litter (ca. $100 \mathrm{mg}$ dry wt) were placed in $20 \mathrm{ml}$ glass scintillation vials containing $10 \mathrm{ml}$ of $2 \%(\mathrm{v} / \mathrm{v})$ filtered $(0.2 \mu \mathrm{m})$, phosphate-buffered formalin (sodium pyrophosphate, $0.1 \%$ $\mathrm{w} / \mathrm{v})$. Bacterial cells attached to litter samples were detached by ultrasonic probe sonication (Cole-Parmer, power output $50 \mathrm{~W}$ ) for $1 \mathrm{~min}$ on ice (see Buesing \& Gessner 2002). After sonication, samples were mixed and sample aliquots (30 to $200 \mu \mathrm{l}$ ) were vacuum filtered $(20 \mathrm{kPa})$ through $25 \mathrm{~mm}$ supported Anodisc filters $(0.2 \mu \mathrm{m}$ pore size, Whatman), with a $0.8 \mu \mathrm{m}$ mixedester membrane backing filter (Fisher Scientific).

Filters were removed, placed sample side up on separate drops of $2.5 \%$ (v/v diluted from stock) SYBR Green I in clean plastic Petri dishes, and stained for 15 min in the dark. Filters were then mounted on glass slides with $30 \mu \mathrm{l}$ antifade mounting solution containing $50 \%$ glycerol, $50 \%$ PBS $(120 \mathrm{mM} \mathrm{NaCl}, 10 \mathrm{mM}$ $\mathrm{NaH}_{2} \mathrm{PO}_{4}$ at $\mathrm{pH} 7.5$ ) and $0.1 \%$ p-phenylenediamine. A $25 \mathrm{~mm}$ circular glass cover slip was then placed on the filter surface and a drop of immersion oil applied (Cargille, Type DF, Formula 1261). Bacterial cells were assigned into 6 categories according to size and shape, and cells were enumerated (1000× magnification) in a minimum of 10 fields ( $\geq 350$ cells) using a Leica DMRB epifluorescence microscope. Video capture photographs were taken for biovolume estimates using a DEI-470 video camera system (Optronics Engineering); 50 photographs of bacteria samples from each wetland site were examined and bacterial size classes measured using Scion Image analysis software (see Gulis \& Suberkropp 2003). Biovolume ( $V$ ) estimates $\left(\mu \mathrm{m}^{-3}\right)$ for each size class were calculated from length $(l)$ and width $(w)$ measurements using the formula $V=\mathrm{w}^{2} / 4 \times(l-w) \times \pi+\mathrm{w}^{3} / 6 \times \pi$. Biovolume estimates were converted to bacterial carbon (fg C) using a formula $\left(\mathrm{C}=89.5 \times V^{0.59}\right)$, which accounts for sizedependent differences in carbon density of bacterial cells (Simon \& Azam 1989).

Fungal productivity and biomass. Instantaneous growth rates of fungi were estimated from rates of $\left[1-{ }^{14} \mathrm{C}\right.$ ]acetate incorporation into ergosterol (see Gessner \& Newell 2002). Subsamples (ca. $0.05 \mathrm{~g}$ AFDM) of leaf litter from litter bags were incubated in sterile $20 \mathrm{ml}$ glass scintillation vials containing $4 \mathrm{ml}$ of filtered $(0.7 \mu \mathrm{m}$, Whatman GF/F) wetland water and $5 \mathrm{mM}$ $\mathrm{Na}\left[1-{ }^{14} \mathrm{C}\right]$ acetate (specific activity $=48 \mathrm{MBq} \mathrm{mmol}^{-1}$, MP Biomedicals) for 4 to $5 \mathrm{~h}$ at $23^{\circ} \mathrm{C}$. Incorporation of $\left[1-{ }^{14} \mathrm{C}\right]$-acetate label was stopped by placing vials on ice and immediately filtering $(0.7 \mu \mathrm{m}$, Whatman $\mathrm{GF} / \mathrm{F})$ the contents. Filters and litter pieces were washed twice with $4 \mathrm{ml}$ of filtered wetland water, placed in scintillation vials, and stored frozen at $-20^{\circ} \mathrm{C}$ until analyzed. Frozen samples were lyophilized, weighed, and ergosterol extracted in alcoholic $\mathrm{KOH}(0.8 \% \mathrm{KOH}$ in HPLC grade methanol, total extraction volume $10 \mathrm{ml}$ ) for $30 \mathrm{~min}$ at $80^{\circ} \mathrm{C}$ in tightly capped digestion tubes 
with constant stirring. The resultant crude litter extract was cleaned by solid phase extraction (Gessner \& Schmitt 1996), and ergosterol was purified and quantified by high pressure liquid chromatography (HPLC). A LichroSpher 100 RP-18 column $(0.46 \times 25 \mathrm{~cm}$, Merck) maintained in a Shimadzu column oven (CTO-10AS) at $40^{\circ} \mathrm{C}$ and connected to a Shimadzu autosampler (SIL10AD) and Shimadzu liquid chromatograph system (Pumps LC-10AT, Controller SCL-10A) was used for separation and analysis. The mobile phase was HPLC grade methanol at a flow rate of $1.5 \mathrm{ml} \mathrm{min}{ }^{-1}$. Ergosterol was detected at $282 \mathrm{~nm}$ using a Shimadzu (SPD10A) UV/VIS detector (retention time $=$ ca. $8 \mathrm{~min}$ ), and was identified and quantified based on comparison with ergosterol standards (Fluka Chemical).

Ergosterol fractions eluting from the HPLC column were collected in $20 \mathrm{ml}$ scintillation vials using an automated Advantec (SF-3120) fraction collector system, mixed with $10 \mathrm{ml}$ of scintillation fluid (Ecolume, MP Biomedicals), and radioactivity assayed by using a Beckman LS 6500 scintillation counter, corrected for quenching. For determination of litter-associated fungal biomass, litter ergosterol concentrations were converted to fungal carbon assuming a conversion factor of $10 \mu \mathrm{g}$ ergosterol $\mathrm{mg}^{-1}$ fungal $\mathrm{C}$, and $50 \% \mathrm{C}$ in fungal dry mass (Gessner \& Newell 2002). For determination of fungal production, rates of acetate incorporation were converted to fungal growth rates, assuming $12.6 \mu \mathrm{g}$ fungal biomass $\mathrm{nmol}^{-1}$ acetate incorporated (Gessner \& Newell 2002).

Microbial respiration. Rates of microbial respiration associated with decomposing Typha angustifolia litter were estimated from measurements of dissolved oxygen consumption (see Carter \& Suberkropp 2004). Subsamples (ca. $0.1 \mathrm{~g}$ AFDM) of leaf litter were placed into small custom-made glass incubation chambers containing ca. $25 \mathrm{ml}$ of filtered ( $0.7 \mu \mathrm{m} \mathrm{GF} / \mathrm{F}$ Whatman) wetland water. Changes in dissolved oxygen concentration within chambers were monitored every $15 \mathrm{~s}$ for 30 min using a YSI 5010L BOD probe connected to a YSI 5100 dissolved oxygen meter (Yellow Springs Instrument). All measurements were conducted in darkness at $23^{\circ} \mathrm{C}$. Additional chambers (ca. 2 to 4 ) containing only filtered wetland water were also monitored as controls. Respiration rates were calculated as the slope of regression lines from samples minus the mean slope of the controls. Rates of oxygen consumption were converted to rates of $\mathrm{CO}_{2}$ evolution, assuming a respiratory quotient of 0.8 .

DOC release. Subsamples of collected litter (ca. $100 \mathrm{mg}$ dry wt) were placed into $50 \mathrm{ml}$ Erlenmeyer flasks containing $25 \mathrm{ml}$ of filtered $(0.7 \mu \mathrm{m} \mathrm{GF} / \mathrm{F}$ Whatman) wetland water for determining the amount of extractable DOC released from decomposing litter (see Komínková et al. 2000). Samples were incubated at $23^{\circ} \mathrm{C}$ for $24 \mathrm{~h}$ on a platform orbital shaker (50 rpm) in darkness. After incubation, samples were filtered through pre-ashed $0.7 \mu \mathrm{m} \mathrm{GF/F} \mathrm{filters} \mathrm{(Whatman).} \mathrm{The}$ resultant filtrates were collected in $20 \times 125 \mathrm{~mm}$ Teflonlined screw cap tubes and the volume measured. Samples were preserved with $250 \mu \mathrm{l}$ concentrated phosphoric acid and stored at $4{ }^{\circ} \mathrm{C}$ until analyzed for DOC using a Shimadzu TOC-500 analyzer. After incubation, litter samples were frozen $\left(-20^{\circ} \mathrm{C}\right)$, lyophilized, weighed and ashed (as above) to determine sample AFDM. All values were corrected for DOC concentrations measured in non-litter containing wetland water controls.

Enzyme assays. Microbial extracellular enzyme activity (EEA) was quantified in 96-well microplates using established fluorometric assays (see Sinsabaugh et al. 2002). Briefly, subsamples (corresponding to ca. $50 \mathrm{mg}$ dry wt) of Typha angustifolia from collected litter bags were placed into $125 \mathrm{ml}$ Nalgene bottles containing $125 \mathrm{ml}$ of $50 \mathrm{mM}, \mathrm{pH} \mathrm{5}$, acetate buffer. Samples were homogenized using a Brinkman polytron and activity assayed for 5 extracellular enzymes. Cellulolytic activity was measured by using assays for $\beta 1,4$-glucosidase (EC.3.2.1.21), cellobiohydrolase (EC.3.2.1.91) and $\beta 1,4$-xylosidase (EC.3.2.1.37). Corresponding fluorometric (methylumbelliferyl, MUB) substrates were 4-MUB- $\beta$-D-glucoside, 4-MUB- $\beta$-Dcellobioside, and 4-MUB- $\beta$-D-xyloside, respectively. Assays for acid phosphatase (EC.3.1.3.2) and $\beta$-n-acetyl-b-glucosaminidase (EC.3.2.1.30), enzymes involved in organic phosphorus and nitrogen acquisition, were assayed using 4-MUB-phosphate and 4-MUB-n-acetyl- $\beta$-glucosaminide, respectively. All assays were conducted at $23^{\circ} \mathrm{C}$ using procedures previously described by Sinsabaugh et al. (1994). Enzyme activities are expressed in units of $\mu \mathrm{mol}$ of substrate converted $\mathrm{g}^{-1}$ detrital $\mathrm{C} \mathrm{h}^{-1}$.

Data analyses. All statistical analyses were performed using SYSTAT (Wilkinson et al. 1992), with differences considered significant at the $\mathrm{p}<0.05$ level. Data were analyzed using repeated-measures ANOVA with site and treatment as grouping factors. All data, if needed (e.g. enzyme activities), were log-transformed prior to analysis in order to achieve a normal distribution and reduce heteroscedasticity. Plant litter decomposition rates $(-k)$ between wetland sites were compared with analysis of covariance (ANCOVA).

\section{RESULTS}

\section{Sedimentation}

Experimental additions of sediment (fine or coarse) to Typha angustifolia litter enclosures did not have a statistically significant effect $(p>0.05)$ on litter mass 
loss, nutrient concentrations, or microbial parameters. However, unforeseen environmental conditions, possibly resulting from hydrologic differences between the 2 study sites (i.e. permanently inundated vs. exposed), may have obscured our ability to experimentally test the effects of increased sedimentation on litter mass loss, nutrient patterns ( $\mathrm{N}$ and $\mathrm{P}$ ), and decay dynamics of litter-inhabiting microbiota. At the LEMP site, surface sediments were always water saturated, but overlying standing water was never present during the study period. As a consequence, experimental sediment additions were applied directly to the exposed litter surface. This applied sediment would dry to the litter surface, but was subject to removal by random precipitation events. Thus, large differences existed between treatment replicates in their duration and exposure to sediment accumulation. In addition, at the permanently inundated WP site, the standing water was naturally turbid and additional sediment applications may not have added significantly to the natural accumulation at this site. Statistically significant differences $(\mathrm{p}<0.05)$ in litter mass loss, nutrient patterns (N and $\mathrm{P}$ ), and decay dynamics of litter-inhabiting microbiota were noted between the 2 wetland sites. Consequently, data were pooled across sediment treatments within each site.

\section{Litter mass loss and nutrient dynamics}

Statistically significant differences in mass loss patterns of Typha angustifolia were observed between the 2 wetland sites $(\mathrm{p}<0.001)$, with $68 \%$ mass loss at the permanently inundated wetland site by $400 \mathrm{~d}$, compared to $55 \%$ mass loss at the exposed site (Fig. 1). The

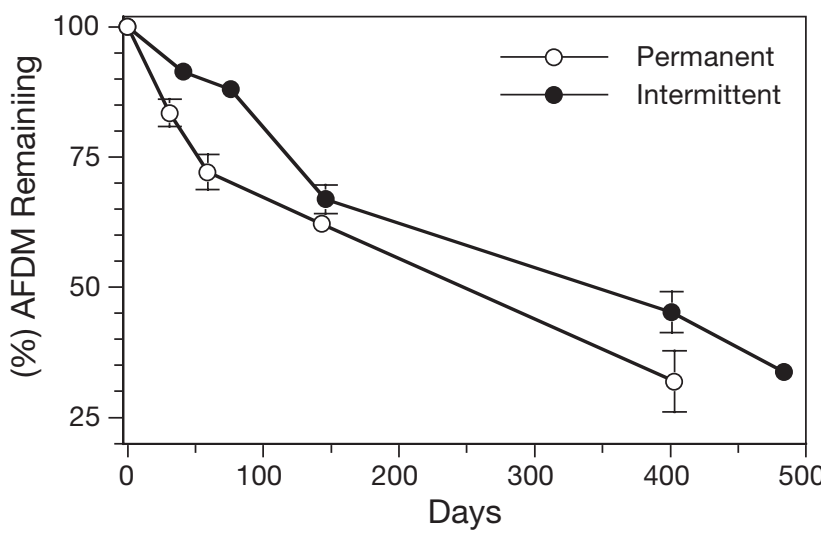

Fig. 1. Typha angustifolia. Mean $\pm \mathrm{SE}(\mathrm{n}=5)$ percent ash-free dry mass (AFDM) of leaf litter remaining in coarse-mesh litter bags at wetland study sites. Permanent, Intermittent: permanently and intermittently inundated sites, respectively. Here and in Figs 2 \& 3, lack of error bars indicates SEs smaller than data points respective decay rate coefficients $(-\mathrm{k})$ were $0.0245 \pm$ $0.0003 \mathrm{~d}^{-1}$ (mean \pm asymptotic standard error, ASE, $\left.\mathrm{r}^{2}=0.64\right)$ and $0.00215 \pm 0.00001 \mathrm{~d}^{-1}\left(\mathrm{r}^{2}=0.87\right)$, and were statistically significantly different $(p<0.05$, ANCOVA). Data on litter mass loss and nutrient concentrations from the permanently inundated (WP) site were not possible for the last sampling date, because insufficient amounts of litter remained in the litter bags; however, the small amount of material that did remain was used for microbial-related analyses.

Statistically significant differences in leaf litter nitrogen $(\mathrm{N})$ and phosphorus $(\mathrm{P})$ concentrations were also observed between the 2 sites $(p<0.01)$. Litter P concentrations increased during decomposition at both study sites (Figs. 2A \& 3A), with higher concentrations of $\mathrm{P}$ accumulating in Typha angustifolia litter at the permanently inundated site vs. the exposed site $(0.17 \%$ vs. $0.12 \%$ after 400 d). Litter $N$ concentrations also increased at both sites during the first $400 \mathrm{~d}$ of decay (Figs. 2B \& 3B). However, in contrast to P concentrations, higher litter $\mathrm{N}$ concentrations were observed at the exposed site $(1.5 \%$ vs. $1.2 \%)$ than at the permanently inundated site. After $400 \mathrm{~d}$, however, $\mathrm{N}$ concentrations decreased significantly (Fig. 3B).

Total amounts of immobilized P (mg) followed a similar trend to P concentrations (Figs. 2A \& 3A). In con-
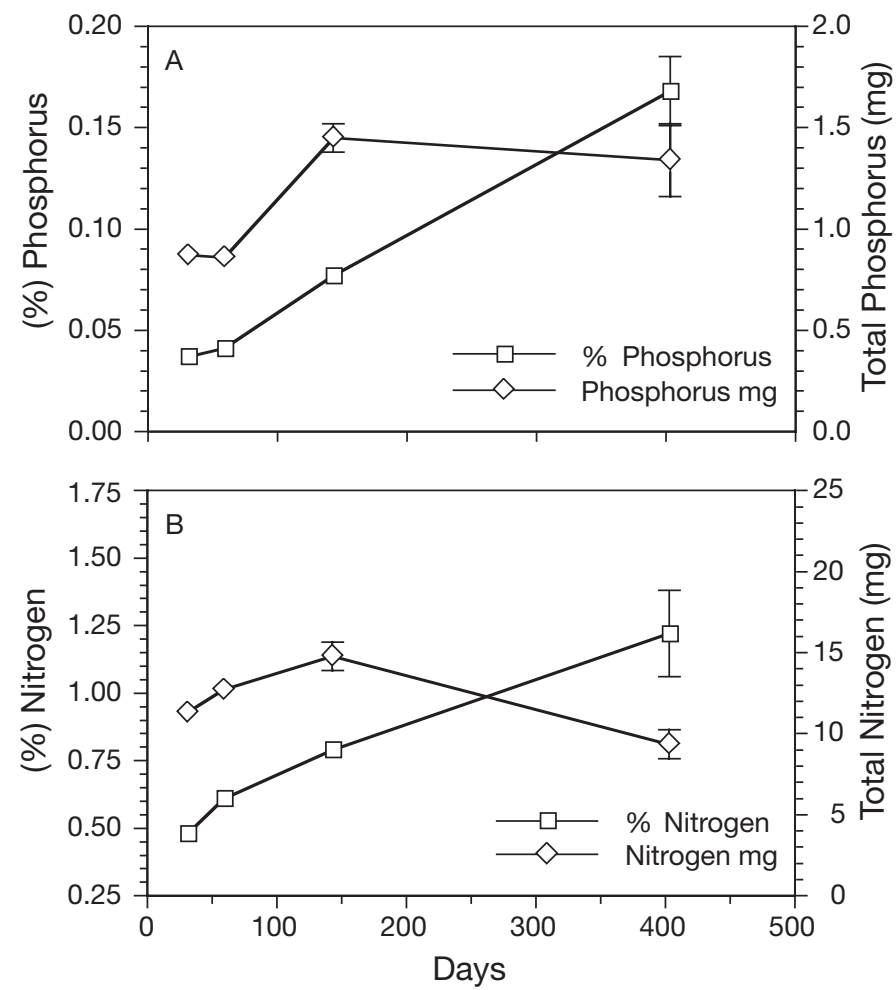

Fig. 2. Typha angustifolia. Mean $\pm \mathrm{SE}(\mathrm{n}=5)$ changes in concentration (\%) and total content (mg) of (A) phosphorus and (B) nitrogen of leaf litter in litter bags at the permanently inundated wetland site (Winous Point) 

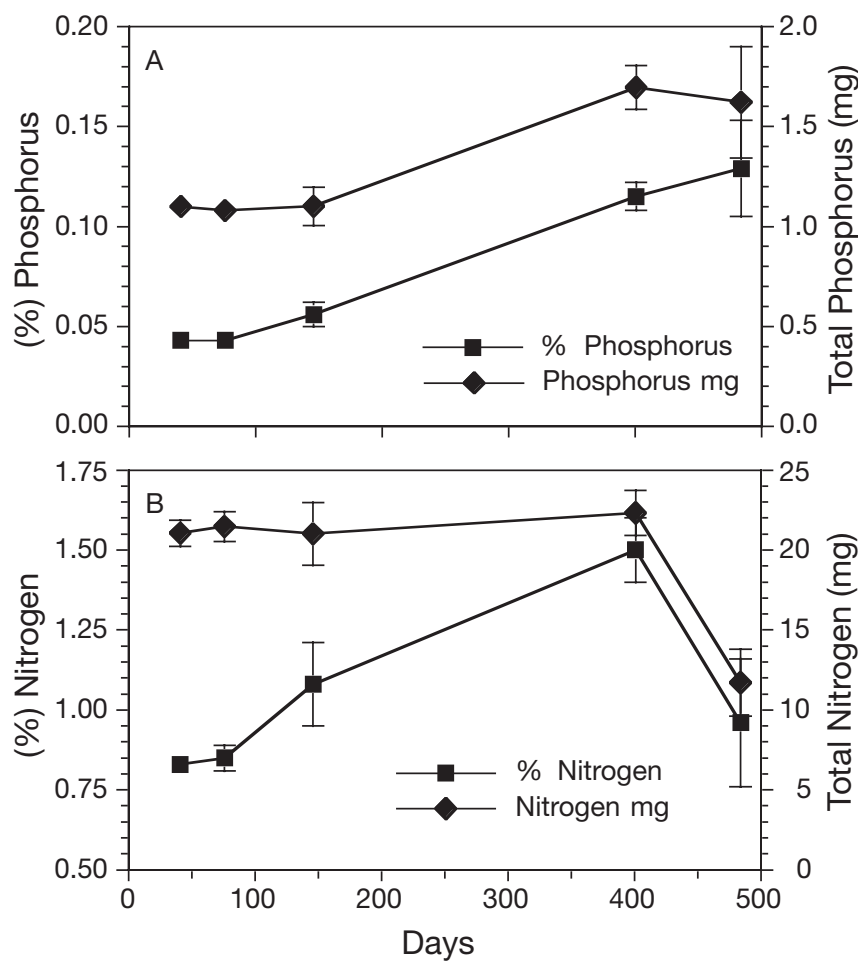

Fig. 3. Typha angustifolia. Mean \pm SE $(n=5)$ changes in concentration $(\%)$ and content $(\mathrm{mg})$ of $(\mathrm{A})$ phosphorus and (B) nitrogen of leaf litter in litter bags at the intermittently inundated wetland site (Lake Erie Metro Park)

trast to $\mathrm{P}$, total amounts of immobilized $\mathrm{N}$ (mg) either remained stable (exposed site) or increased slightly (inundated site) during the initial phases of litter decay, followed by a statistically significant decrease $(\mathrm{p}<0.05)$ in total $\mathrm{N}$ at both sites by the end of the study period (Figs. 2B \& 3B). Statistically significant differences in total $\mathrm{N}$ were observed between the study sites ( $\mathrm{p}<0.001)$, with litter at the permanently flooded site having markedly lower total N (20 to $58 \%$ ) throughout the study period.

\section{Microbial biomass and production}

Throughout the study period there were statistically significant differences in litter-associated microbial biomass (fungi) and production (bacteria and fungi) between the 2 sites $(p<0.001)$. Fungal biomass concentrations on decaying Typha angustifolia leaf litter were 2 to 4 times higher at the exposed site than the permanently inundated site (Fig. 4A). At the exposed site, litter-associated fungal biomass increased to a maximum of $125 \pm 20 \mathrm{mg} \mathrm{C} \mathrm{g}^{-1}$ detrital C (October, $146 \mathrm{~d}$ ), then decreased to $74 \mathrm{mg} \mathrm{C} \mathrm{g}^{-1}$ detrital $\mathrm{C}$ by the last sampling date $(484 \mathrm{~d})$. Fungal biomass associated with submerged litter at the permanently in-
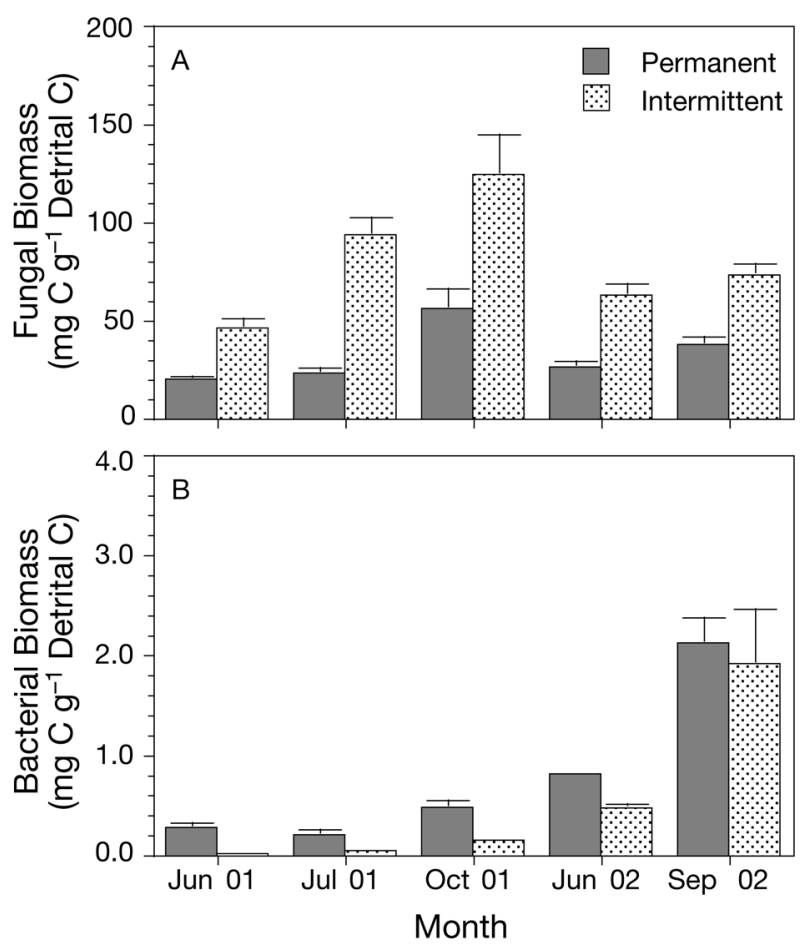

Fig. 4. Typha angustifolia. Mean $+\mathrm{SE}(\mathrm{n}=5)(\mathrm{A})$ fungal and (B) bacterial biomass associated with decomposing leaf litter at the 2 wetland study sites

undated site followed a similar seasonal trend, but values reached a maximum of only $57 \pm 10 \mathrm{mg} \mathrm{C} \mathrm{g}^{-1}$ detrital C.

Bacterial biomass associated with decaying Typha angustifolia leaves showed a statistically significant increase $(p<0.001)$ during litter decay at both sites (Fig. 4B). In contrast to fungal biomass patterns, bacterial biomass was higher ( 2 to 13 times) at the permanently inundated site during most of the study period, but this difference was not statistically significant $(p>0.05)$. Despite the apparent differences between study sites (e.g. hydrologic), fungal decomposers accounted for $\geq 94 \%$ of total microbial biomass associated with decaying $T$. angustifolia litter (Table 1).

Fungal growth rates $\left(\mu_{\mathrm{f}}, \mathrm{P}: \mathrm{B}\right)$ associated with Typha angustifolia were higher on average at the permanently inundated site $\left(4.2 \pm 3.3 \% \mathrm{~d}^{-1}\right)$ than the exposed site $\left(2.7 \pm 0.7 \% \mathrm{~d}^{-1}\right)$, despite the potential for oxygen limitation (Table 1). Consequently, a higher overall biomass turnover time was observed for fungi colonizing litter at the exposed site ( $37 \mathrm{~d}$ ) relative to the permanently inundated site $(24 \mathrm{~d})$. Similarly, bacterial growth rates $\left(\mu_{b}, P: B\right)$ associated with decaying $T$. angustifolia litter were also higher on average at the permanently inundated site $\left(0.84 \pm 0.89 \% \mathrm{~d}^{-1}\right)$ than the exposed site $\left(0.53 \pm 0.4 \% \mathrm{~d}^{-1}\right)$. However, these $\mu_{\mathrm{b}}$ were 
Table 1. Mean \pm SE $(n=5)$ biomass and growth characteristics of fungal and bacterial assemblages associated with decomposing Typha angustifolia leaf litter at 2 contrasting wetland sites. Microbial growth efficiencies $=$ fungal + bacterial production/fungal + bacterial production + respiration $\times 100$. LEMP: Lake Erie Metro Park; WP: Winous Point

\begin{tabular}{|c|c|c|c|c|c|}
\hline Parameter & Jun 01 & Jul 01 & Oct 01 & Jun 02 & Sep 02 \\
\hline \multicolumn{6}{|l|}{ Intermittent exposure site (LEMP) } \\
\hline Fungal:microbial biomass (\%) & $99.9 \pm 0.01$ & $99.9 \pm 0.02$ & $99.9 \pm 0.02$ & $99.2 \pm 0.08$ & $97.6 \pm 0.53$ \\
\hline Fungal:microbial production (\%) & $99.9 \pm 0.01$ & $99.9 \pm 0.01$ & $99.9 \pm 0.01$ & $99.9 \pm 0.02$ & $99.9 \pm 0.03$ \\
\hline Fungal growth rates $\left(\% \mathrm{~d}^{-1}\right)$ & $2.11 \pm 0.35$ & $5.27 \pm 0.10$ & $2.07 \pm 0.21$ & $2.15 \pm 0.16$ & $2.97 \pm 0.43$ \\
\hline Bacterial growth rates $\left(\% \mathrm{~d}^{-1}\right)$ & $0.51 \pm 0.17$ & $1.27 \pm 0.33$ & $0.41 \pm 0.11$ & $0.30 \pm 0.04$ & $0.18 \pm 0.10$ \\
\hline Microbial growth efficiency (\%) & $18 \pm 3$ & $54 \pm 3$ & $33 \pm 3$ & $19 \pm 1$ & $29 \pm 6$ \\
\hline \multicolumn{6}{|l|}{ Permanently flooded site (WP) } \\
\hline Fungal:microbial biomass (\%) & $98.6 \pm 0.27$ & $99.1 \pm 0.24$ & $99.1 \pm 0.16$ & $96.9 \pm 0.33$ & $94.5 \pm 0.84$ \\
\hline Fungal:microbial production (\%) & $99.4 \pm 0.28$ & $99.6 \pm 0.04$ & $99.7 \pm 0.10$ & $99.8 \pm 0.07$ & $99.8 \pm 0.09$ \\
\hline Fungal growth rates $\left(\% \mathrm{~d}^{-1}\right)$ & $3.34 \pm 0.42$ & $4.36 \pm 0.25$ & $1.75 \pm 0.64$ & $9.84 \pm 2.06$ & $1.80 \pm 0.73$ \\
\hline Bacterial growth rates $\left(\% \mathrm{~d}^{-1}\right)$ & $1.16 \pm 0.20$ & $2.24 \pm 0.46$ & $0.24 \pm 0.05$ & $0.56 \pm 0.16$ & $0.02 \pm 0.002$ \\
\hline Microbial growth efficiency (\%) & $12 \pm 2$ & $21 \pm 4$ & $9 \pm 2$ & $25 \pm 5$ & $4 \pm 1$ \\
\hline
\end{tabular}

ca. 5 times lower than corresponding $\mu_{\mathrm{f}}$ (Table 1), indicating bacterial turnover times of 118 and $185 \mathrm{~d}$ for bacterial assemblages at the exposed and permanently inundated sites, respectively.

Rates of fungal and bacterial production followed a similar pattern to that of fungal and bacterial biomass. Production rates for fungi were consistently higher on leaf litter at the exposed wetland site (Fig. 5A), with the exception of June 2002 (Fig. 5B). Likewise, rates of bacterial production were consistently higher at the
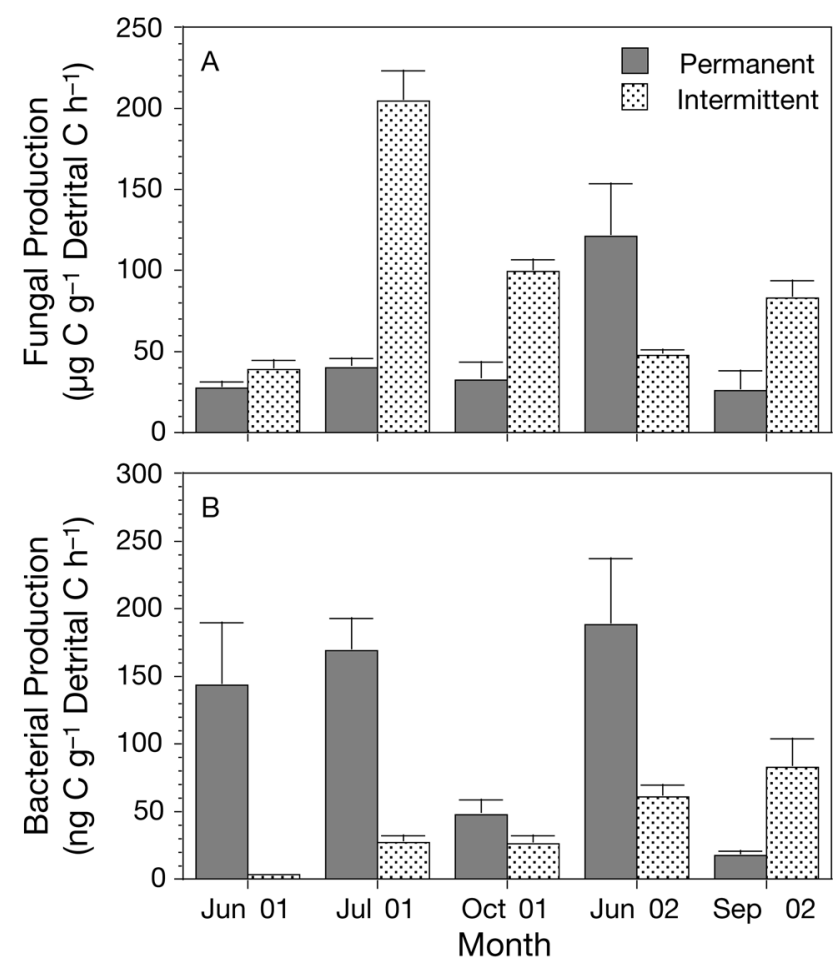

Fig. 5. Typha angustifolia. Mean + SE $(n=5)(A)$ fungal and (B) bacterial production rates associated with decomposing leaf litter at the 2 wetland study sites permanently inundated site, except on the last sampling date (September 2002) when higher productivities were observed at the exposed site. Estimated microbial production rates associated with decaying Typha angustifolia litter at both wetland sites were largely dominated by fungi, which accounted for $\geq 99 \%$ of the total microbial production during each sampling period (Table 1).

\section{Microbial respiration}

Rates of microbial respiration from Typha angustifolia leaves were similar at both wetland sites during the initial stages of litter decomposition, with a mean rate of $191 \pm 49$ and $170 \pm 7 \mu \mathrm{g} \mathrm{C} \mathrm{g}^{-1}$ detrital $\mathrm{C} \mathrm{h}^{-1}$ recorded at the permanent and intermittent site during July 2001 (59 and 76 d), respectively (Fig. 6). Rates of microbial respiration associated with litter at the intermittent wetland site increased only slightly $(p=0.08)$ during the study period, with an average rate of $245 \pm$ $39 \mu \mathrm{g} \mathrm{C} \mathrm{g}^{-1}$ detrital $\mathrm{C} \mathrm{h}^{-1}$ on the last sampling date

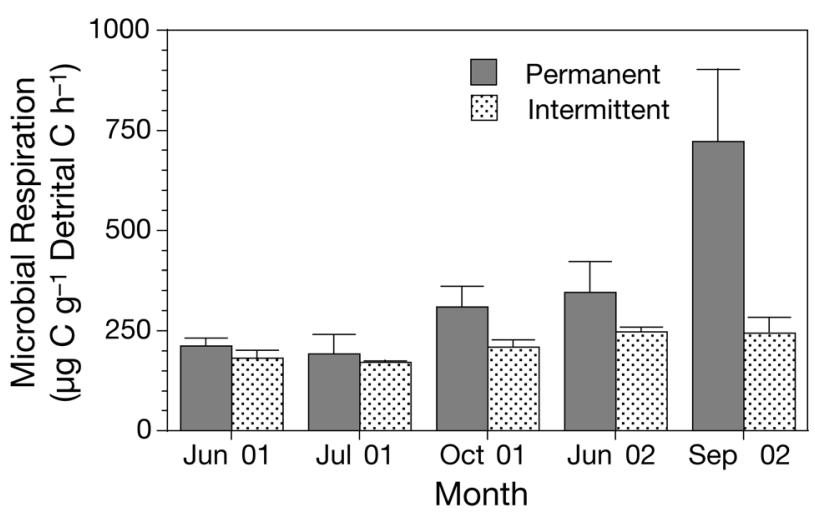

Fig. 6. Typha angustifolia. Mean $+\mathrm{SE}(\mathrm{n}=5)$ rates of microbial respiration from leaf litter at the 2 wetland study sites 
(Fig. 6). In contrast, microbial respiration rates at the permanently inundated site showed a statistically significant increase $(p<0.001)$ throughout litter decay, with a final value approximately 3.4 times higher than that observed at the beginning of the study period $\left(720 \pm 180 \mu \mathrm{g} \mathrm{C} \mathrm{g}^{-1}\right.$ detrital $\left.\mathrm{C} \mathrm{h}^{-1}\right)$.

\section{DOC release}

The release of extractable DOC from Typha angustifolia litter was statistically significantly different between sites ( $p<0.001)$, with up to 55 times greater release rates from decaying litter at the exposed wetland site than at the permanently inundated site (Fig. 7). At the exposed site, maximum release of DOC from decaying leaf litter $\left(6.51 \pm 0.88 \mathrm{mg} \mathrm{C} \mathrm{g}^{-1}\right.$ detrital $\mathrm{C} \mathrm{d}^{-1}$ ) was observed on the first sampling date, with subsequent rates declining over the study period. In contrast, maximum release of DOC from litter at the permanently inundated site $\left(2.25 \pm 0.25 \mathrm{mg} \mathrm{C} \mathrm{g}^{-1}\right.$ detrital $\mathrm{C} \mathrm{d}^{-1}$ ) occurred near the end of the study period (Fig. 7), coinciding with increases in rates of bacterial and fungal production (Fig. 5A).

\section{Enzyme activities}

Activities of microbial degradative enzymes involved in the acquisition of $\mathrm{P}$ (acid phosphatase), $\mathrm{N}$ ( $\beta$-n-acetylglucosaminidase) and $C$ ( $\beta$-glucosidase, cellobiohydrolase, $\beta$-xylosidase) from decaying plant litter (Figs. 8 \& 9) followed patterns similar to those described previously for fungal biomass (Fig. 4A). In general, potential enzyme activities per $\mathrm{g}$ detrital $\mathrm{C}$ were consistently higher at the exposed wetland site throughout the duration of the study. Differences in the distribution of EEA between the 2 decomposer communities are more apparent when

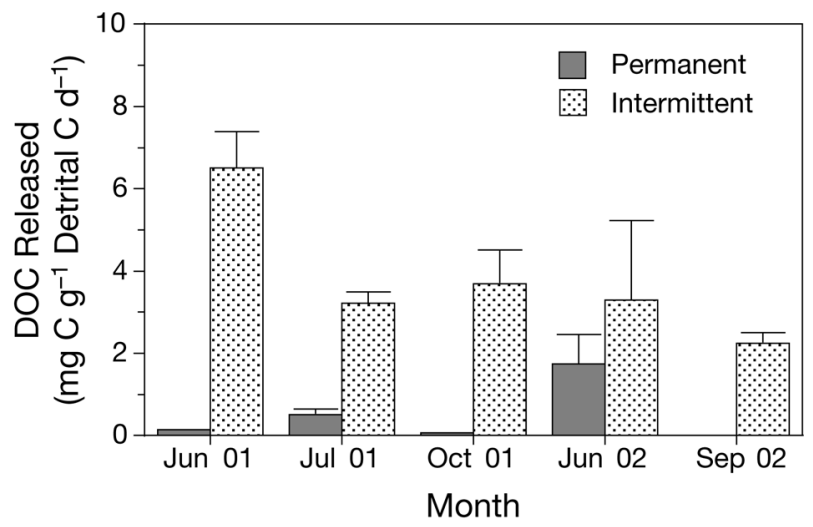

Fig. 7. Typha angustifolia. Mean $+\mathrm{SE}(\mathrm{n}=5)$ release rates of extractable dissolved organic carbon (DOC) from decomposing leaf litter at the 2 wetland study sites
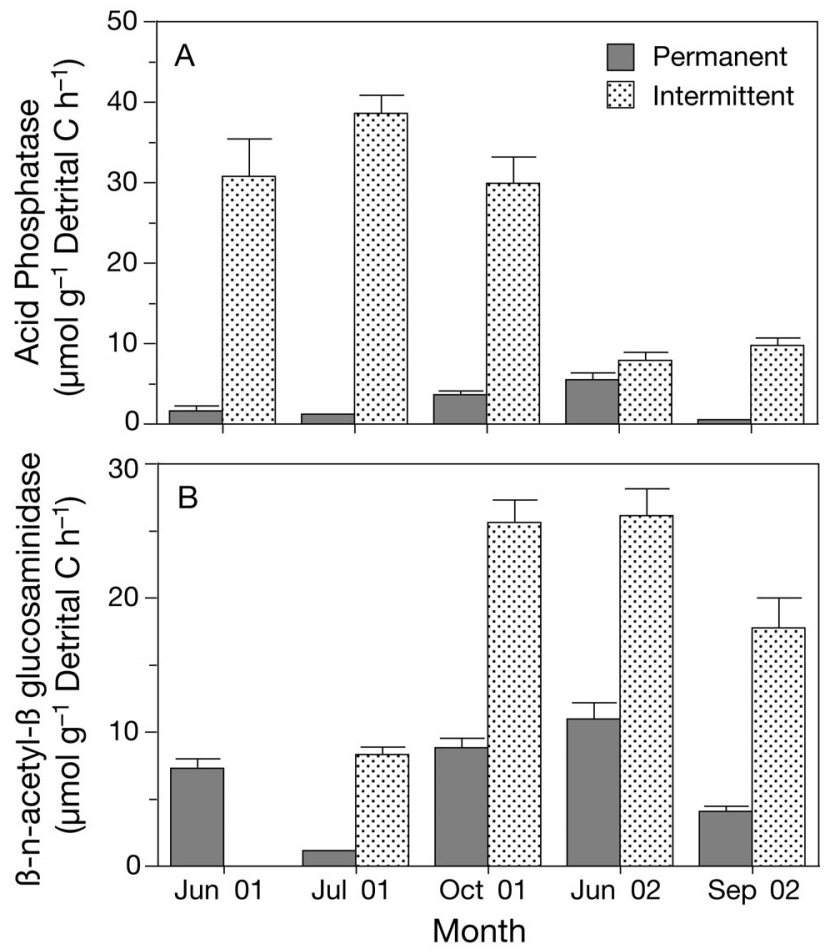

Fig. 8. Typha angustifolia. Mean + SE $(n=5)$ (A) acid phosphatase and (B) $\beta$-n-acetyl- $\beta$-glucosaminidase enzyme activity associated with decomposing leaf litter at the 2 wetland study sites

activities are compared per mg microbial biomass $\mathrm{C}$ (MBC). Phosphatase showed the largest differences in biomass-specific activity, averaging $330 \pm 250 \mathrm{nmol} \mathrm{mg}$ $\mathrm{MBC}^{-1} \mathrm{~h}^{-1}$ at the exposed LEMP site, but only $86 \pm$ $81 \mathrm{nmol} \mathrm{mg} \mathrm{MBC}{ }^{-1} \mathrm{~h}^{-1}$ at the inundated WP site, suggesting that cycling of $\mathrm{P}$ within the community was more extensive at the exposed site. Specific cellulolytic activities were also higher at the exposed site, by about 2-fold (910 vs. $440 \mathrm{nmol} \mathrm{mg} \mathrm{MBC}^{-1} \mathrm{~h}^{-1}$ for $\beta$-glucosidase, 300 vs. $110 \mathrm{nmol} \mathrm{mg} \mathrm{MBC}{ }^{-1} \mathrm{~h}^{-1}$ for cellobiohydrolase, $180 \mathrm{vs}$. $140 \mathrm{nmol} \mathrm{mg} \mathrm{MBC}{ }^{-1} \mathrm{~h}^{-1}$ for $\beta$-xylosidase). $\beta$-n-acetylglucosaminidase was the exception to this trend in that biomass-specific activities were similar at both sites, averaging $200 \mathrm{nmol} \mathrm{mg} \mathrm{MBC}^{-1} \mathrm{~h}^{-1}$ for the intermittent LEMP site and $220 \mathrm{nmol} \mathrm{mg} \mathrm{MBC}{ }^{-1} \mathrm{~h}^{-1}$ for the flooded WP site.

\section{DISCUSSION}

In contrast to previous studies (e.g. Vargo et al. 1998), we did not observe any statistically significant effects of sedimentation (size or loading rates) on Typha angustifolia mass loss patterns or litter nutrient concentrations. Furthermore, we observed no statistically significant effects of sedimentation on the biomass and activities of fungi and bacteria associated with decomposing T. angustifolia litter. However, as 

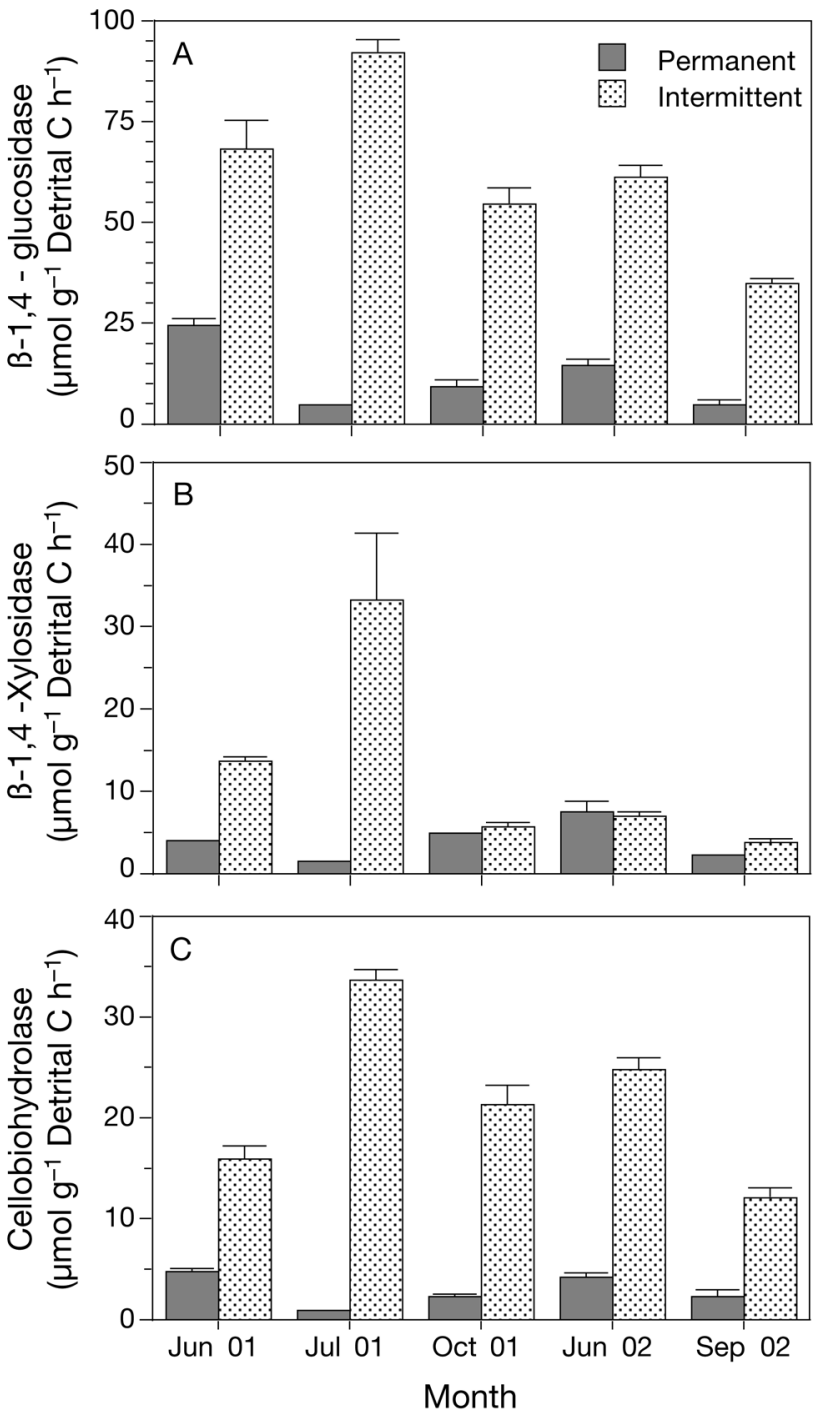

Fig. 9. Typha angustifolia. Mean $+\mathrm{SE}(\mathrm{n}=5)(\mathrm{A}) \beta-1,4$-glucosidase, (B) $\beta$-1,4-xylosidase, and (C) cellobiohydrolase enzyme activity associated with decomposing leaf litter at the 2 wetland study sites

suggested previously, unforeseen environmental conditions, possibly resulting from hydrologic differences between the 2 study sites, may have obscured our ability to test the effects of sedimentation on microbial decay processes.

We did observe statistically significant differences in overall mass loss patterns and microbial decay processes between the 2 hydrologically distinct wetland sites. Over the $400 \mathrm{~d}$ study period, Typha angustifolia litter at the permanently inundated site lost $13 \%$ more of its initial mass than litter at the exposed site and had a statistically significantly higher rate constant. However, most of this difference appeared in the first sampling interval; thereafter decay rates between the 2 sites were roughly similar
Table 2. Typha angustifolia. Mass loss rates of at wetland study sites. $k$ : litter decay rate; $M_{0}$ : initial ash-free dry mass in litter bags; ASE: asymptotic standard error

\begin{tabular}{|lccc|}
\hline $\begin{array}{l}\text { Period } \\
(\mathrm{d})\end{array}$ & $\begin{array}{c}k \pm \mathrm{ASE} \\
\left(\mathrm{d}^{-1}\right)\end{array}$ & $\begin{array}{c}M_{0} \pm \mathrm{ASE} \\
(\%)\end{array}$ & $\begin{array}{c}\mathrm{r}^{2} \\
(\text { corrected) }\end{array}$ \\
\hline $\begin{array}{l}\text { Intermittent exposure site (LEMP) } \\
0-484\end{array}$ & & \\
$41-484$ & $-0.0022 \pm 0.00008$ & $99.7 \pm 1.3$ & 0.90 \\
$76-484$ & $-0.0022 \pm 0.00010$ & $99.5 \pm 1.9$ & 0.87 \\
Permanently flooded site (WP) & & \\
$0-403$ & $-0.0029 \pm 0.00025$ & $93.4 \pm 3.1$ & 0.73 \\
$31-403$ & $-0.0025 \pm 0.00027$ & $87.3 \pm 3.2$ & 0.63 \\
$59-403$ & $-0.0023 \pm 0.00030$ & $83.7 \pm 4.6$ & 0.90 \\
\hline
\end{tabular}

(Table 2), indicating that differences in mass loss rates between the 2 systems were largely the result of initial processes (including leaching).

The higher mass loss rates at the permanently inundated site were consistent with some reports of litter processing under flooded vs. exposed conditions (Gurtz \& Tate 1988, Neckles \& Neill 1994, Glazebrook \& Robertson 1999, Kelley \& Jack 2002). Kelley \& Jack (2002) suggested that submergence promoted faster litter decay through greater leaching losses, higher microbial metabolism, and feeding by aquatic detritivores. However, other studies have found faster rates of mass loss for litter experiencing intermittent cycles of inundation and exposure (Ryder \& Horwitz 1995, Lockaby et al. 1996, Battle \& Golladay 2001).

Battle \& Golladay (2001) examined the effects of differing hydroperiods on litter decomposition of pond cypress Taxodium ascendens and swamp black gum Nyssa sylvatica var. biflora in 3 depressional wetlands of the Gulf Coast plain. They reported faster decomposition rates in wetlands experiencing multiple flooding and exposure events relative to single flooding events or continuously submerged habitats. Because microbial biomass associated with decaying litter was similar across sites, the authors hypothesized that cycles of flooding and drying accelerated litter decomposition by increasing aeration, leading to greater microbial activity. Ryder \& Horwitz (1995) reported similar findings for the decomposition of 2 emergent macrophytes, Baumea articulata and Typha orientalis, in seasonal and permanent wetlands of the Swan coastal plain of western Australia. Leaf litter in seasonally inundated sites had higher rates of mass loss and greater microbial biomass (total phospholipids).

In the present study, statistically significant differences in litter nutrient dynamics were also observed between wetland sites. Both $\mathrm{N}$ and $\mathrm{P}$ concentrations increased during litter decomposition at both sites. Total $\mathrm{N}$ either remained stable (exposed site) or increased slightly (permanent site) during early litter decay, followed by a de- 
crease at the end of the study period. However, total $\mathrm{N}$ was considerably lower (e.g. 20 to $58 \%$ ) at the permanently flooded site throughout the study period, suggesting that there was substantial $\mathrm{N}$ exchange (i.e. leaching) within the water column. At the exposed site, there was less $\mathrm{N}$ loss from leaching and greater retention of immobilized $\mathrm{N}$. The pattern was similar for total $\mathrm{P}$, which was about $20 \%$ lower on average at the permanently inundated wetland site.

Similar patterns in litter nutrient dynamics have been reported for other wetland habitats (Neckles \& Neill 1994, Lockaby et al. 1996, Glazebrook \& Robertson 1999, Battle \& Golladay 2001). Neckles \& Neill (1994) reported that the percentage of original $\mathrm{N}$ remaining in aboveground litter of the emergent plant Scolochloa festucacea declined in treatment sites experiencing longer periods of inundation. However, total $\mathrm{N}$ in $\mathrm{S}$. festucacea litter subsequently increased in sites exposed to longer flooding regimes, suggesting that litter submergence accelerated the initial leaching losses of $\mathrm{N}$ and probaly promoted decomposer-mediated uptake and immobilization of dissolved $\mathrm{N}$ during later stages of litter decay (Neckles \& Neill 1994).

Submergence of plant litter permits continual exchanges of $\mathrm{C}, \mathrm{N}, \mathrm{P}$ and mineral nutrients between the microbial decomposer community and the surrounding ecosystem. For litter exposed to an aerial environment (e.g. exposed sediments or standingdead), the exchange of organic compounds and essential nutrients may be restricted to periods of inundation and throughfall. During the intervals between these events, the decomposition process is more restricted. As a result, substrate depletion and metabolite accumulation may limit microbial activity and increase competition for available nutrients. One metric of limited hydrologic exchange is the accumulation of soluble organic compounds in aerial litter. Throughout the study period, the extractable DOC concentration in litter exposed at the LEMP site was 2 to 55 times greater than that of submerged litter at the WP site. In the absence of leaching, this DOC may be metabolized in situ, rather than entering the water column for consumption in the microbial loop.

Comparisons of enzyme activity patterns for emergent and submersed litter also show the effects of limited hydrologic exchange. When calculated $\mathrm{mg}^{-1} \mathrm{MBC}$ phosphatase activity associated with emergent litter was, on average, 4 times greater than activity associated with the flooded litter. If activity is calculated per unit of microbial production, then the litters differ by a factor of 11, indicating that a large portion of microbial $\mathrm{P}$ demand within emergent litter was met through internal cycling, rather than uptake from the environment. For cellulolytic activities, average potentials per unit $\mathrm{MBC}$ were twice as large for the exposed litter (6 times greater if activities are compared per unit of production) than those associated with submerged litter, suggesting that microbial communities in exposed litter were more dependent on cellulose for carbon. NAGase was the interesting exception. Activities per unit microbial biomass and production were similar for aerial and submerged litter, suggesting that activity of this chitindegrading enzyme was more directly linked to microbial biomass and productivity than to litter degradation.

The microbial community associated with exposed litter at the LEMP site was characterized by high biomass, high rates of production, high specific extracellular enzyme activity, and high growth efficiencies compared to submerged litter at WP. As a consequence, we would have expected litter mass loss rates to be significantly higher at LEMP. However, it is likely that the high metabolic potentials associated with exposed litter were realized during relatively narrow temporal periods, similar to those observed in standing-dead decay systems (see Kuehn \& Suberkropp 1998b, Kuehn et al. 2004). The more aerobic conditions at the exposed site promoted the growth of fungal decomposers, which can often metabolize at water potentials below those of bacteria. Nonetheless, it is likely that most of the decomposition activity occurred during periods of inundation, precipitation or dew formation. For LEMP, restricted windows for microbial activity were offset by the higher activity potentials. As a result, after initial leaching losses, mass loss rates were similar to those for submerged litter at WP.

At WP, submergence of litter buffered the decomposer community from environmental fluctuations, but may also have limited metabolic activity through lower oxygen availability, which averaged $<2 \mathrm{mg} \mathrm{l}^{-1}$. Submerged Typha angustifolia litter had higher bacterial biomass and production, and lower fungal biomass and production, than exposed litter. Previous studies have reported decreases in litter-associated fungal biomass and production rates in response to submergence (Komínková et al. 2000, Kuehn et al. 2000), supporting the idea that bacteria may assume an increased role in litter decay after collapse of litter to the overlying surface waters (Newell et al. 1995). Although bacteria biomass and production were greater for submerged than for exposed litter, the net effect of litter submergence was a decrease in total microbial biomass and production (Figs. 4 \& 5), accompanied by lower specific extracellular enzyme activities (Figs. 8 \& 9) and growth efficiencies (Table 1). Hence, in contrast to LEMP, T. angustifolia litter mass loss at WP was characterized by lower, but more sustained, metabolic activity, that was equally effective in transforming litter carbon.

Rates of fungal growth on Typha angustifolia litter at LEMP (2.36 $\mathrm{mg} \mathrm{C} \mathrm{g}^{-1}$ detrital $\mathrm{C} \mathrm{d}^{-1}$ ) and WP (1.18 mg C $\mathrm{g}^{-1}$ detrital $\mathrm{C} \mathrm{d}^{-1}$ ) were comparable to those reported 
for other freshwater habitats (Table 3). In contrast, estimates for litter-associated bacteria were substantially lower in comparison to those in other published studies (Table 3). Average turnover times yielded estimates that were abnormally high, suggesting problems in our ability to accurately quantify production rates of bacterial communities attached to decaying litter (e.g. isotope dilution). Rates of microbial respiration were more similar between sites than production rates, averaging $5.1 \mathrm{mg} \mathrm{C} \mathrm{g}^{-1}$ detrital $\mathrm{C} \mathrm{d}^{-1}$ at LEMP and $8.6 \mathrm{mg}$ $\mathrm{C} \mathrm{g}^{-1}$ detrital $\mathrm{C} \mathrm{d}^{-1}$ at WP. As a result, the mean microbial growth efficiencies of 30 and $14 \%$ for LEMP and $\mathrm{WP}$, respectively, were within the range reported in other decomposition studies (Table 3). The greater efficiency at LEMP is consistent with the higher specific enzyme activities, higher DOC concentration, and higher $\mathrm{N}$ and $\mathrm{P}$ content of exposed litter.

Vascular plant litter is an important structural component in all wetlands. However, its specific contributions to ecosystem trophic structure and nutrient dynamics reflect the metabolism of the associated decomposer communities. This study has resolved some of the mechanisms by which edaphic and hydrologic variables may control microbial decay dynamics and mediate carbon and nutrient exchange between litter and the water column.

Table 3. Range of microbial fungal and bacterial production (ash-free dry mass, AFDM) and growth rate estimates associated with decaying litter under submerged or sediment-surface conditions in freshwater habitats. Corresponding microbial growth efficiencies are also noted. Sch: Schulz; PC: Payne Creek; WB: Walker Branch; HWC: High White Creek; BS: Basin Creek; HM: Hendrick Mill, LSB: Lindsey Spring Branch; LEMP: Lake Erie Metro Park; WP: Winous Point; -: no data

\begin{tabular}{|c|c|c|c|c|c|c|}
\hline \multirow[t]{2}{*}{ Species } & \multicolumn{2}{|c|}{$\begin{array}{c}\text { Production } \\
\left(\mu g \mathrm{C} \mathrm{g}^{-1} \mathrm{AFDM} \mathrm{d} \mathrm{d}^{-1}\right)\end{array}$} & \multicolumn{2}{|c|}{$\begin{array}{l}\text { Growth rates } \\
\qquad\left(\% d^{-1}\right)\end{array}$} & \multirow[t]{2}{*}{$\begin{array}{c}\text { Growth } \\
\text { efficiency }(\%)\end{array}$} & \multirow[t]{2}{*}{ Source } \\
\hline & Fungi & Bacteria & Fungi & Bacteria & & \\
\hline Juncus effusus & - & $10-810^{\mathrm{a}}$ & - & - & - & Moran et al. (1989) \\
\hline Panicum hemitomen & - & $20-88^{\mathrm{a}}$ & - & - & - & Moran et al. (1989) \\
\hline Typha latifolia & - & $280-420^{\mathrm{a}}$ & - & - & - & Moran et al. (1989) \\
\hline Trapa natans & - & $0-77$ & - & $2.8-10.0$ & - & Findlay et al. (1990) \\
\hline Carex walteriana & - & $0.5-31$ & - & - & - & Moran \& Hodson (1992) \\
\hline Juncus effusus & - & $11-760^{a, b}$ & - & $6.6-20.7^{b}$ & - & Thomaz \& Wetzel (1995) \\
\hline Mixed hydrophytes & $19-2500^{\mathrm{b}}$ & $8-35^{\mathrm{b}}$ & $4.2-11.1^{\mathrm{b}}$ & $2.7-50.0^{\mathrm{b}}$ & $3-31$ & Sinsabaugh \& Findlay (1995) \\
\hline Carex walteriana & $115-403^{\mathrm{b}}$ & $1-22^{\mathrm{b}}$ & $0.4-4.5^{\mathrm{b}}$ & $0.4-2.6^{\mathrm{b}}$ & - & Newell et al. (1995) \\
\hline Liriodendron tulipifera (Sch) & $33-3258^{\mathrm{c}}$ & $18-107^{\mathrm{c}}$ & $0.7-15.6$ & - & - & Weyers \& Suberkropp (1996) \\
\hline Liriodendron tulipifera (PC) & $6-266^{\mathrm{c}}$ & $6-19^{c}$ & $0.1-16.0$ & - & - & Weyers \& Suberkropp (1996) \\
\hline Alnus glutinosa & $50-500$ & $25-625$ & $0.1-40.0$ & $3.0-8300$ & $2-12$ & Baldy \& Gessner (1997) \\
\hline Mixed deciduous & $315-1358^{\mathrm{b}, \mathrm{c}}$ & - & $0.9-7.0^{\mathrm{b}}$ & - & - & Suberkropp (1997) \\
\hline Juncus effusus & $73-2836$ & $4-32$ & $0.7-16.9$ & $4.0-14.6$ & - & Kuehn et al. (2000) \\
\hline Phragmites australis & & & & & & Komínková et al. (2000) \\
\hline Leaves & $185-614^{\mathrm{d}}$ & - & $0.5-1.9$ & - & $13-50^{\mathrm{e}}$ & \\
\hline Sheaths/culm & $41-103$ & - & $0.7-1.8$ & - & $7-49^{\mathrm{e}}$ & \\
\hline Liriodendron tulipifera (WB) & $23-2624^{c}$ & - & $0.1-9.4$ & - & - & Suberkropp (2001) \\
\hline Quercus alba (WB) & $113-1386$ & - & $0.2-5.6$ & - & & Suberkropp (2001) \\
\hline Liriodendron tulipifera (HWC) & $131-491$ & - & $0.4-2.3$ & - & & Suberkropp (2001) \\
\hline Quercus alba (HWC) & $36-392$ & - & $0.3-1.4$ & - & & Suberkropp (2001) \\
\hline Populus gr. Nigra & $50-700^{\mathrm{d}}$ & $1-210^{\mathrm{d}}$ & $0.4-10.2$ & $6.0-150$ & - & Baldy et al. (2002) \\
\hline Typha angustifolia & $40-715^{\mathrm{a}}$ & $0.2-1.6^{\mathrm{a}}$ & $0.1-3.7$ & $7.1-12.5$ & - & Findlay et al. (2002) \\
\hline Phragmites australis & $30-211$ & $0.3-0.5$ & $0.1-0.3$ & - & - & Findlay et al. (2002) \\
\hline Mixed deciduous (BS) & $441-2687^{\mathrm{b}, \mathrm{c}}$ & - & $1.7-16.5^{\mathrm{b}}$ & - & & Methvin \& Suberkropp (2003) \\
\hline Mixed deciduous (HM) & $608-2947^{\mathrm{b}, \mathrm{c}}$ & - & $1.5-11.6^{\mathrm{b}}$ & - & & Methvin \& Suberkropp (2003) \\
\hline Mixed deciduous (LSB) & $207-3596^{\mathrm{b}, \mathrm{c}}$ & - & $1.0-10.4^{\mathrm{b}}$ & - & $7-65^{\mathrm{e}}$ & Carter \& Suberkropp (2004) \\
\hline Mixed deciduous (PC) & $279-4392^{\mathrm{b}, \mathrm{c}}$ & - & $0.2-4.2^{\mathrm{b}}$ & - & $14-50^{\mathrm{e}}$ & Carter \& Suberkropp (2004) \\
\hline Alnus glutinosa & $700-3600^{\mathrm{d}}$ & $13-138^{\mathrm{d}}$ & $2.8-47.9$ & - & $\begin{array}{c}14-00 \\
-\end{array}$ & Pascoal \& Cássio (2004) \\
\hline Phragmites australis & $100-1200^{\mathrm{b}, \mathrm{d}}$ & $1300-9400^{\mathrm{b}, \mathrm{d}}$ & $1.0-6.0^{\mathrm{b}}$ & $200-800^{b}$ & $30-66$ & Buesing \& Gessner (2006) \\
\hline Typha angustifolia (LEMP) & $473-2477^{d}$ & $0.04-1.0^{\mathrm{d}}$ & $2.1-5.3$ & $0.2-1.3$ & $16-54$ & Present study \\
\hline Typha angustifolia (WP) & $337-1378^{\mathrm{d}}$ & $0.2-2.3^{\mathrm{d}}$ & $1.8-9.8$ & $0.02-2.2$ & $4-26$ & Present study \\
\hline \multicolumn{7}{|c|}{ 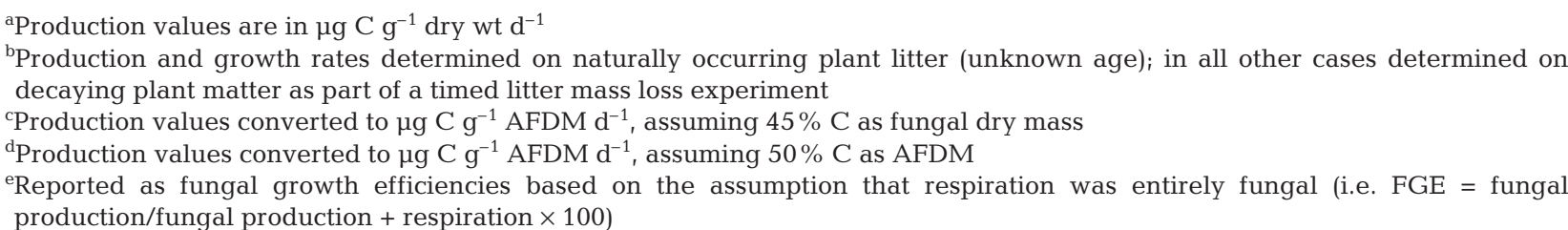 } \\
\hline
\end{tabular}


Acknowledgements. The authors thank A. J. Foley for help in litter ergosterol determinations and S. Lenart for assistance in bacterial epifluorescence direct count microscopy. In addition, we thank J. Smith for sharing dry mass data for litter bags from the Lake Erie Metro Park wetland site. We also thank the Winous Point Conservation Area and the HuronClinton Metropolitan Authority for allowing access to the wetland study sites where this research was conducted. This research was supported by grants from the National Oceanographic and Atmospheric Administration Michigan SeaGrant Consortia (NOAA, No. R/CW-15) and the National Science Foundation (DEB-0315686). Partial support for R.S. was provided by Meta Hellwig Research Scholarship Program from the Department of Biology, Eastern Michigan University.

\section{LITERATURE CITED}

Baldy V, Gessner MO (1997) Towards a budget of leaf litter decomposition in a first order woodland stream. CR Acad Sci Sér III 320:747-758

Baldy V, Chauvet E, Charcosset JY, Gessner MO (2002) Microbial dynamics associated with leaves decomposing in the mainstem and floodplain pond of a large river. Aquat Microb Ecol 28:25-36

Baley SE, Mewhort RL (2004) Plant community structure and junctional differences between marshes and fens in the southern boreal region of Alberta, Canada. Wetlands 24: 277-294

Battle JM, Golladay SW (2001) Hydroperiod influence on breakdown of leaf litter in cypress-gum wetlands. Am Mid Nat 146:128-145

Brinson MM, Lugo AE, Brown S (1981) Primary productivity, decomposition and consumer activity in freshwater wetlands. Annu Rev Ecol Syst 12:123-161

Buesing N, Gessner MO (2002) Comparison of detachment procedures for direct counts of bacteria associated with sediment particles, plant litter and epiphytic biofilms. Aquat Microb Ecol 27:29-36

Buesing N, Gessner MO (2006) Benthic bacterial and fungal productivity and carbon turnover in a freshwater marsh. Appl Environ Microbiol 72:596-605

Carter MD, Suberkropp K (2004) Respiration and annual fungal production associated with decomposing leaf litter in two streams. Freshw Biol 49:1112-1122

Findlay S, Howe K, Austin HK (1990) Comparison of detritus dynamics in two tidal freshwater wetlands. Ecology 71: 288-295

Findlay SEG, Dye S, Kuehn KA (2002) Microbial growth and nitrogen retention in litter of Phragmites australis compared to Typha angustifolia. Wetlands 22:616-625

Gessner MO, Newell SY (2002) Biomass, growth rate, and production of filamentous fungi in plant litter. In: Hurst CJ, Crawford RL, Knudsen G, McInerney M, Stezenbach LD (eds) Manual of environmental microbiology, 2nd edn. American Society for Microbiology, Washington, DC, p 390-408

Gessner MO, Schmitt AL (1996) Use of solid-phase extraction to determine ergosterol concentration in plant tissue colonized by fungi. Appl Environ Microbiol 62:415-419

Glazebrook HS, Robertson AI (1999) The effect of flooding and flood timing on leaf breakdown rates and nutrient dynamics in a river red gum (Eucalyptus camaldulensis) forest. Aust J Ecol 24:625-635

Gulis V, Suberkropp K (2003) Leaf litter decomposition and microbial activity in nutrient-enriched and unaltered reaches of a headwater stream. Freshw Biol 48:123-134
Gurtz ME, Tate CM (1988) Hydrologic influences on leaf decomposition in a channel adjacent bank of a gallery forest stream. Am Mid Nat 120:11-21

Herdendorf CE, Hartley SM, Barnes MD (eds) (1981) Fish and wildlife resources of the Great Lakes coastal wetlands within the United States. Vol 1: Overview. United States Fish and Wildlife Service, Office of Biological Services, Washington DC (FWS/OBS-81/02-VI)

Hopkinson CS (1992) A comparison of ecosystem dynamics in freshwater wetlands. Estuaries 15:549-562

Kelley RH, Jack JD (2002) Leaf litter decomposition in an ephemeral karst lake (Chaney Lake, Kentucky, USA). Hydrobiologia 482:41-47

Komínková D, Kuehn KA, Büsing N, Steiner D, Gessner MO (2000) Microbial biomass, growth, and respiration associated with submerged litter of Phragmites australis decomposing in a littoral reed stand of a large lake. Aquat Microb Ecol 22:271-282

Kuehn KA, Suberkropp K (1998a) Decomposition of standing litter of the freshwater emergent macrophyte Juncus effusus. Freshw Biol 40:717-727

Kuehn KA, Suberkropp K (1998b) Diel fluctuations in microbial activity associated with standing-dead litter of the freshwater emergent macrophyte Juncus effusus. Aquat Microb Ecol 14:171-182

Kuehn KA, Lemke MJ, Suberkropp K, Wetzel RG (2000) Microbial biomass and production associated with decaying leaf litter of the emergent macrophyte Juncus effusus. Limnol Oceanogr 45:862-870

Kuehn KA, Steiner D, Gessner MO (2004) Diel mineralization patterns of standing-dead plant litter: implications for $\mathrm{CO}_{2}$ flux from wetlands. Ecology 85:2504-2518

Lockaby BG, Wheat RS, Clawson RG (1996) Influence of hydroperiod on litter conversion to soil organic matter in a floodplain forest. Soil Sci Soc Am J 60:1989-1993

Mann KH (1988) Production and use of detritus in various freshwater, estuarine and coastal marine ecosystems. Limnol Oceanogr 33:910-930

Martin DC, Neely RK (2000) Benthic macroinvertebrate response to sedimentation in a freshwater wetland. Wetlands Ecol Manag 9:441-454

Methvin BR, Suberkropp K (2003) Annual production of leafdecaying fungi in 2 streams. J N Am Benthol Soc 22: 554-564

Mitsch WJ, Gosselink JG (2000) Wetlands, 3rd edn. John Wiley \& Sons, New York

Moran MA, Hodson RE (1989) Bacterial secondary production on vascular plant detritus: relationships to detritus composition and degradation rate. Appl Environ Microbiol 55: 2178-2189

Moran MA, Hodson RE (1992) Contribution of three subsystems of a freshwater marsh to total bacterial secondary productivity. Microb Ecol 24:161-170

Neckles HA, Neill C (1994) Hydrological control of litter decomposition in seasonally flooded prairie marshes. Hydrobiologia 286:55-65

Newell SY, Moran MA, Wicks R, Hodson RE (1995) Productivities of microbial decomposers during early stages of decomposition of leaves of a freshwater sedge. Freshw Biol 34:135-148

Noble RT, Fuhrman JA (1998) Use of SYBR Green I for rapid epifluorescence counts of marine viruses and bacteria. Aquat Microb Ecol 14:113-118

Pascoal C, Cássio F (2004) Contribution of fungi and bacteria to leaf litter decomposition in a polluted river. Appl Environ Microbiol 70:5266-5273

Polunin NVC (1984) The decomposition of emergent macro- 
phytes in fresh water. Adv Ecol Res 14:115-166

Ryder DS, Horwitz P (1995) Seasonal water regimes and leaf litter processing in a wetland on the Swan Coastal plain, Western Australia. Mar Freshw Res 46:1077-1084

Simon M, Azam F (1989) Protein content and protein synthesis rates of planktonic marine bacteria. Mar Ecol Prog Ser 51:201-213

Sinsabaugh RL, Findlay S (1995) Microbial production, enzyme activity, and carbon turnover in surface sediments of the Hudson River Estuary. Microb Ecol 30:127-141

Sinsabaugh RL, Osgood MP, Findlay S (1994) Enzymatic models for estimating decomposition rates of particulate detritus. J N Am Benthol Soc 13:160-169

Sinsabaugh RL, Carreiro MM, Alvarez S (2002) Enzyme and microbial dynamics of litter decomposition In: Burns RG (ed) Enzymes in the environment: activity, ecology, and applications. Marcel Dekker, New York, p 249-265

Suberkropp K (1997) Annual production of leaf-decaying fungi in a woodland stream. Freshw Biol 38:168-178

Suberkropp K (2001) Fungal growth, production, and sporulation during leaf decomposition in two streams. Appl Environ Microbiol 67:5063-5068

Editorial responsibility: Lars Tranvik, Uppsala, Sweden
Thomaz SM, Wetzel RG (1995) $\left[{ }^{3} \mathrm{H}\right]$ leucine incorporation methodology to estimate epiphytic bacterial biomass production. Microb Ecol 29:63-70

Vargo MS, Neely RK, Kirkwood SM (1998) Emergent plant decomposition and sedimentation: response to sediments varying in texture, phosphorus content and frequency of deposition. Environ Exper Bot 40:43-58

Webster JR, Benfield EF (1986) Vascular plant breakdown in freshwater ecosystems. Annu Rev Ecol Syst 17:567-594

Wetzel RG (1990) Landwater interfaces: metabolic and limnological regulators. Int Ver Theor Angew Limnol Verh 24: $6-24$

Wetzel RG (1992) Wetlands as metabolic gates. J Gt Lakes Res 18:529-532

Wetzel RG, Howe MJ (1999) High production in a herbaceous perennial plant achieved by continuous growth and synchronized population dynamics. Aquat Bot 64: 111-129

Weyers HS, Suberkropp K (1996) Fungal and bacterial production during the breakdown of yellow poplar leaves in 2 streams. J N Am Benthol Soc 15:408-420

Wilkinson L, Hill MA, Welna JP, Birkenbeuel GK (1992) Systat 5 for the Macintosh, Version 5.2. Systat, Evanston, IL

Submitted: May 22, 2006; Accepted: October 10, 2006

Proofs received from author(s): February 6, 2007 